\title{
Induction of reactive oxygen species in brain of Etroplus maculatus after exposure to bisphenol $\mathrm{A}$
}

\author{
R. Rejitha ${ }^{1}$, K. P. Asifa ${ }^{1}$ and K. C. Chitra ${ }^{1^{*}}$ \\ ${ }^{1}$ Department of Zoology, University of Calicut, Malappuram-673635 (Kerala), INDIA \\ *Corresponding author. E-mail: kcchitra@yahoo.com \\ Received: July 12, 2015; Revised received: November 24, 2015; Accepted: March 10, 2016
}

\begin{abstract}
The present study was aimed to investigate that bisphenol A, an environmental estrogen, exposed at 648 $\mu \mathrm{g} / \mathrm{L}$ concentration for $96 \mathrm{~h}$ could induce reactive oxygen species in brain of cichlid fish, Etroplus maculatus. Evaluation of antioxidant enzymes as superoxide dismutase, catalase and glutathione reductase showed a reduction in the activities at $5 \%$ level of significance with concomitant increase in the level of hydrogen peroxide generation (from $1.546 \pm 0.426$ (control), $1.506 \pm 0.217$ (DMSO) to $1.888 \pm 0.368$ (24 h), $5.332 \pm 0.589$ (72 h), $2.392 \pm$ $0.341(96 \mathrm{~h})$ ) and lipid peroxidation (from $2.805 \pm 0.33$ (control), $2.401 \pm 0.309$ (DMSO) to $3.596 \pm 0.373$ (24 h), 5.65 $\pm 0.306(72 \mathrm{~h}), 3.834 \pm 0.236(96 \mathrm{~h})$ ). The brain marker enzyme, acetylcholinesterase decreased at 24,72 and $96 \mathrm{~h}$ in time-dependent manner than that of control groups. The present findings summarize that the increased production of oxygen free radicals due to the exposure of an environmental estrogen, bisphenol $A$ at sub lethal concentration $(648 \mu \mathrm{g} / \mathrm{L})$ for $96 \mathrm{~h}$ inhibited the activities of antioxidant enzymes thereby induced oxidative stress in brain of fish. The decreased activity of brain marker enzyme, acetylcholinesterase reflect the neurotoxicity of bisphenol $A$ in brain of fish, Etroplus maculatus and this could be one of the possible mechanisms of bisphenol A-induced neurodevelopmental disorders in fish.
\end{abstract}

Keywords: Acetyl cholinesterase, Bisphenol A, Brain, Etroplus maculatus, Oxidative stress, ROS

\section{INTRODUCTION}

Bisphenol A (BPA), an organic high-volume industrial chemical, is widely used in the production of epoxy resins and polycarbonate plastics. Epoxy resins are known to prevent corrosion in metallic products that are often used as inner liners of metallic food and drink containers. However, polycarbonate plastics are the unavoidable products of many domestic materials, notably food and drink containers (US FDA, 2012). BPA is also used as a coating on some form of thermal paper that are often used as receipts from cash registers, automatic teller machines, and other similar devices. In polyvinyl chloride (PVC) industries and in metal foundries it is profoundly used to make casts and moldings. Therefore the primary route of human exposure to BPA is believed to be through diet as it leaches from canned food and beverage containers that are lined with epoxy resin coatings, and from polycarbonate plastic products (Krishnan et al., 1993). Leaching of BPA into food occurs mainly by warming the plastic in a microwave, where temperature appears to be a more important factor in leaching than the age of the container. Other possible sources of BPA exposure include air, dust, water, and dental sealants (Vandenberg et al., 2007). Estimated human consumption of BPA from epoxy-lined food cans alone was 6.6 $\mu \mathrm{g} /$ person/day (Howe and Borodinsky, 1998).
Earlier biomonitoring studies such as pharmokinetic and health risk assessment revealed that BPA exposure is prevalent in the United States and other developed countries. BPA has been detected in $94.3 \%$ of human samples from India at concentrations ranging from 0.1 to $30.1 \mathrm{ng} / \mathrm{ml}$ and are associated with polycystic ovarian syndrome, diabetes, hypertension and metabolic syndrome (Zhang et al., 2011). Non-monotonic dose response curve studies have demonstrated BPA as an endocrine disrupting chemical having estrogenic activity in vivo and in vitro (Diamanti-Kandarakis et al., 2009). Endocrine disruptors usually mimic natural hormones and act by interfering with the biosynthesis, secretion, action, or metabolism of naturally occurring hormones. BPA is a "weakly estrogenic" chemical, because its affinity for binding to estrogen receptors is approximately 10,000-fold weaker than natural estrogen (Kuiper et al., 1998).

BPA has been found in lakes, rivers, and the ocean, as well as in sediments and soils. BPA in water bodies is most frequently the result of its presence in municipal wastewater discharges and in leachate from landfills. Effluents containing BPA are therefore a primary source of BPA contamination in the aquatic environment. It was disclosed that two oxidative enzymes namely peroxidase and polyphenol oxidase, are associated with BPA metabolism. Photolysis and photooxidation are the main non-biological pathways of 
BPA breakdown in the aquatic environment (Kang et al., 2007). Consequently the threat to BPA on aquatic life is alarming as the standardized tests for screening and evaluating endocrine disruptors has evidenced the effect of BPA on various systems in different animals and proved as estrogenic. One of the recent studies reported that the abnormal brain development in mice is through the X-mediated effect and this could result in neuro developmental disorders induced by BPA exposure (Kumamoto and Oshio, 2013). Nevertheless, the information on the induction of reactive oxygen species in brain of cichlid fish is one of the new aspects to prove the toxicity effect of BPA in aquatic life. Based on the above lack of evidence the present work has been designed to study the effect of bisphenol A on the reactive oxygen species generation in brain of cichlid fish, Etroplus maculatus. The present study is a standardized and precise in vivo screening test used to evaluate the adverse effects of bisphenol A on the fish brain antioxidant system, which also provide useful information if exposure to bisphenol A at sublethal concentration for $96 \mathrm{~h}$ could induce reactive oxygen species in the brain of fish, E. maculatus.

\section{MATERIALS AND METHODS}

Animal: Cichlid fish, E. maculatus weighing $7 \pm 1 \mathrm{~g}$ and length $6.5 \pm 1 \mathrm{~cm}$ were collected from a fish farm, Kaloos Aquarium, Kotakkal, Malappuram District, Kerala, India. Fishes were acclimatized to laboratory conditions prior to the experiments for four weeks with constant supply of water and good lighting system. They were maintained in well-aerated tubs $(40 \mathrm{~L}$ capacity), which was dechlorinated and bath was changed regularly at every $24 \mathrm{~h}$.

Standardization: The physico-chemical features of the tap water were estimated as per APHA (1998). Water temperature in the test ranged from $28 \pm 2{ }^{\circ} \mathrm{C}$ during the experiment, oxygen saturation of water ranged between 70 and $100 \%, \mathrm{pH}$ is 6.5 to 7.5 which were monitored using standardized procedures as prescribed by APHA. Preliminary tests were conducted to provide guidance on the range of concentration of bisphenol $\mathrm{A}$ in the experiment. $\mathrm{LC}_{50}$ determined by probit analysis was observed as $6.48 \mathrm{mg} / \mathrm{L}$ (Asifa and Chitra, 2015a).

Chemicals: Bisphenol A (4, 4 Isopropylidenediphenol) of $97 \%$ purity was obtained from SISCO Research Laboratories Pvt. Ltd., Mumbai, India. Malondialdehyde, NADPH, glutathione oxidized, thiobarbituric acid, pyrogallol, acetylthiocholine iodide (ATC), 5,5' dithiobis-2-dinitrobenzoic acid (DTNB) were obtained from Himedia Laboratories, Mumbai, India. All other chemicals were of analytical grade and obtained from local commercial sources.

Treatment: Fishes in each treatment groups were maintained separately in aquarium tanks $(60 \mathrm{~cm}$ X 30 $\mathrm{cm}$ X $30 \mathrm{~cm}$ ) covered with monofilament netting to prevent the escape of specimens out of test solutions.
The behaviour of fishes was observed and death was also recorded throughout the study. One-tenth of the $\mathrm{LC}_{50}$ concentration $(648 \mu \mathrm{g} / \mathrm{L})$ of bisphenol A was chosen in the present study as sublethal concentration. $1 \%$ Dimethyl sulfoxide (1\% DMSO) was used as an organic solvent to dissolve bisphenol A (BPA), therefore it was used as a positive control in the experiment. In the experiment totally 5 groups were maintained as follows with 10 animals in each group.

Group I - Negative control: Fishes was maintained in toxicant-free water.

Group II - Positive control: Fishes was maintained in $1 \%$ DMSO.

Group III: Fishes are treated with $648 \mu \mathrm{g} / \mathrm{L}$ for $24 \mathrm{~h}$. Group IV: Fishes are treated with $648 \mu \mathrm{g} / \mathrm{L}$ for $72 \mathrm{~h}$. Group V: Fishes are treated with $648 \mu \mathrm{g} / \mathrm{L}$ for $96 \mathrm{~h}$. The fish was caught very gently using a small dip net, one at a time with least disturbance. At the end of each exposure time, fishes were weighed and brain was dissected in both control and treated groups and stored at $4^{\circ} \mathrm{C}$ until the biochemical analyses were performed.

Preparation of tissue homogenate and biochemical analyses: $1 \%(\mathrm{w} / \mathrm{v})$ homogenate of whole brain was prepared in ice-cold normal saline with the help of a motor-driven glass Teflon homogenizer on crushed ice for a minute. The homogenate was centrifuged at 8000 $g$ for $15 \mathrm{~min}$ at $4^{\circ} \mathrm{C}$ to obtain the supernatant, which was then used for the analyses.

Protein was estimated by the method of Lowry et al. (1951) with BSA as the standard. Activities of superoxide dismutase (Marklund and Marklund, 1974), catalase (Claiborne, 1985), glutathione reductase (Carlberg and Mannervik, 1985), level of lipid peroxidation (Ohkawa et al., 1979), hydrogen peroxide generation (Pick and Keisari, 1981), acetyl cholinesterase (Ellman et al., 1961) was estimated in crude homogenate of control and treatment groups.

Statistics: Statistical analyses were performed using one-way analysis of variance (ANOVA) followed by Duncan's Multiple Range test using statistical package SPSS 17.0. Differences were considered to be significant at $\mathrm{p}<0.05$ against control group. Data are presented as mean $\pm \mathrm{SD}$ for ten animals per group. All biochemical estimations were carried out in duplicate.

\section{RESULTS AND DISCUSSION}

Bisphenol A, one of the endocrine disrupting estrogenic environmental contaminants are of great concern in recent years as it is an important industrial compound as well as a major component of epoxy and polystyrene resins used in food packaging and as a protective coating (Safe et al., 2001). To examine the effect of BPA on antioxidant system in brain tissue in one of the cichlid fishes, E. maculatus the evaluation of the activities of antioxidant enzymes are negligible. In addition the activity of one of the brain marker enzymes, acetyl cholinesterase was also examined for short-term duration i.e., $96 \mathrm{~h}$. In the present study 
when fishes exposed to $1 \%$ DMSO did not showed significant variations in any parameters including body weights, organ weight and biochemical parameters (Fig. 1-8). Acute exposure to BPA for three durations such as $24 \mathrm{~h}, 72 \mathrm{~h}$ and $96 \mathrm{~h}$ showed a significant $(\mathrm{P}<0.05)$ reduction in the body weight of the animals than the control groups and this may be due to treatment related anorexia or failure of orientation towards food (Fig. 1). The weight of brain tissue was decreased significantly $(\mathrm{P}<0.05)$ after BPA treatment at $96 \mathrm{~h}$ exposure and this could be due to systemic toxicity of the compound (Fig. 2).

Fishes are relatively very sensitive organism that reflects the changes in behavior when the surrounding environment is polluted as evidenced by behavioural modifications in fish exposed to toxicants as chlordecone, phthalate and nanoparticles (Asifa and Chitra, 2015b; Revathy and Chitra, 2015; Sumi and Chitra, 2015). It is well known that BPA is released into the aquatic environment through either sewage treatment effluent, landfill leachate or natural degradation of polycarbonate plastics (Meesters and Wa, 2002). It finally enters into the body of aquatic animals; especially fishes thus creating challenges for humans, since fish is the commonly used protein food. Fish health may thus reflect, and present as a good health indicator of an aquatic ecosystem. Acute toxic effects of pollution can be evident on identifying fish behavior or external appearance of fish after exposure to any contaminants. One of our studies have reported that acute BPA exposure alters the normal behavior of fish as reflected by erratic swimming activity followed by restricted movements, haemorrhagic on entire body surface, reddening of fins and finally loss of equilibrium (Asifa and Chitra, 2015a). Apart from the fish behavior, the biochemical changes at cellular or tissue level provides an additional evident of acute toxicity of BPA in aquatic environment. Therefore, the present study focused on the effect of BPA in antioxidant system of brain tissues in E. maculatus.

Studies on heavy metal toxicity and volatile organic compounds indicate that the toxicity in aquatic organisms when exposed to any anthropogenic agents may be associated with increased production of reactive oxygen species (ROS), leading to oxidative stress (Livingstone, 2001; Batista et al., 2014). In almost all aquatic animals are provided with constitutive or enhanced antioxidant defense systems, but some of the contaminants increased levels of oxidative damage in spite of its defensive mechanisms and therefore stimulate the production of ROS (Livingston, 2001). These contaminants may promote the production of superoxide anion radicals by redox cycling, while transition metals such as iron catalyze the reaction of superoxide anion radicals and hydrogen peroxide to produce hydroxyl radicals through Fenton reactions (Winston and Giulio, 1991). ROS, including superoxide, hydrogen peroxide, and hydroxyl radical damage various cell components such as unsaturated lipids, proteins, and nucleic acids. Oxidative stress caused by ROS production in cell is largely formed by alternative activities of scavenger proteins or by dysfunction of the mitochondrial respiratory chain pathway (Kabuto et al., 2003). In the present study, acute administration of BPA at $648 \mu \mathrm{g} / \mathrm{L}$ significantly $(\mathrm{P}<0.05)$ decreased the activities of antioxidant enzymes as superoxide dismutase (Fig. 3), catalase (Fig. 4), glutathione reductase (Fig. 5) in 24, 72 and $96 \mathrm{~h}$ treatment groups of brain tissues when compared to control groups. Superoxide dismutase (SOD) is an antioxidant enzyme that catalysis the dismutation of superoxide to hydrogen peroxide $\left(\mathrm{H}_{2} \mathrm{O}_{2}\right)$ and oxygen $\left(\mathrm{O}_{2}\right)$. The conversion of $\mathrm{H}_{2} \mathrm{O}_{2}$ to $2 \mathrm{H}_{2} \mathrm{O}$ is by the enzyme glutathione peroxidase and the conversion of $\mathrm{H}_{2} \mathrm{O}_{2}$ to $\mathrm{O}_{2}$ and $\mathrm{H}_{2} \mathrm{O}$ is by the enzyme catalase. Glutathione peroxidase/ reductase directly act as antioxidant enzymes to inhibit lipid peroxidation (Sikka et al., 2001). In the present study a decrease in the activity of superoxide dismutase has been shown to increase the level of superoxide anion, which is known to inactivate catalase activity (Sahin and Gumuslu, 2004). The level of hydrogen peroxide showed a significant increase at $5 \%$ level of significance at $72 \mathrm{~h}$ and $96 \mathrm{~h}$ treatment groups (Fig 6). This could be due to the reduction in catalase or glutathione reductase activity, which could have resulted in the failure of elimination of hydrogen peroxide from the cell and thus hydrogen peroxide get accumulated in brain tissues (Ekambaram et al., 2012).

Level of lipid peroxidation increased significantly $(\mathrm{P}<0.05)$ in 24,72 and $96 \mathrm{~h}$ treatment groups than that of control groups (Fig. 7). Increased lipid peroxidation may indicate failure of elimination of hydrogen peroxide and an increased oxygen free radical generation (Thiele et al., 1995). When hydrogen peroxide is accumulated at low concentration it is not reactive, but at a higher concentration in the presence of $\mathrm{Fe}^{2+}$ promotes the formation of highly toxic hydroxyl radicals, which attack almost all biomolecules including membrane lipids in brain tissues causing the production of lipid peroxides (Halliwell, 1993).

BPA at low concentration have been shown to cause oxidative stress in epididymal sperm (Chitra et al., 2002) and testis of rats (Bindhumol et al., 2003). BPA has been shown to alter antioxidant defense system where it impaired aerobic metabolism in gill and altered the state of inter and intracellular membrane transport in liver of fish, Oreochromis mossambicus (Chitra and Sajitha, 2014; Chitra and Maiby, 2014).

BPA is a known endocrine disruptor and it is likely to alter neurobehaviour as it was evident that acute exposure to BPA affects the locomotion and equilibrium of fish E. maculatus (Asifa and Chitra, 2015a). Activity of acetylcholinesterase (AChE) is widely used as a biomarker to detect the effect of any contaminant on neuromuscular functions of fish. In the present study the activity of acetyl cholinesterase showed a time- 


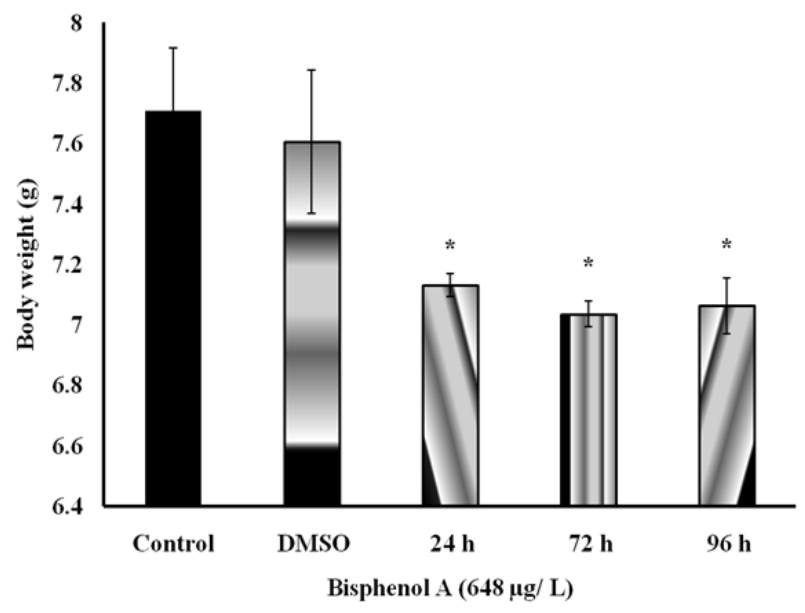

Fig. 1. Effect of bisphenol A on body weights of E. maculates.

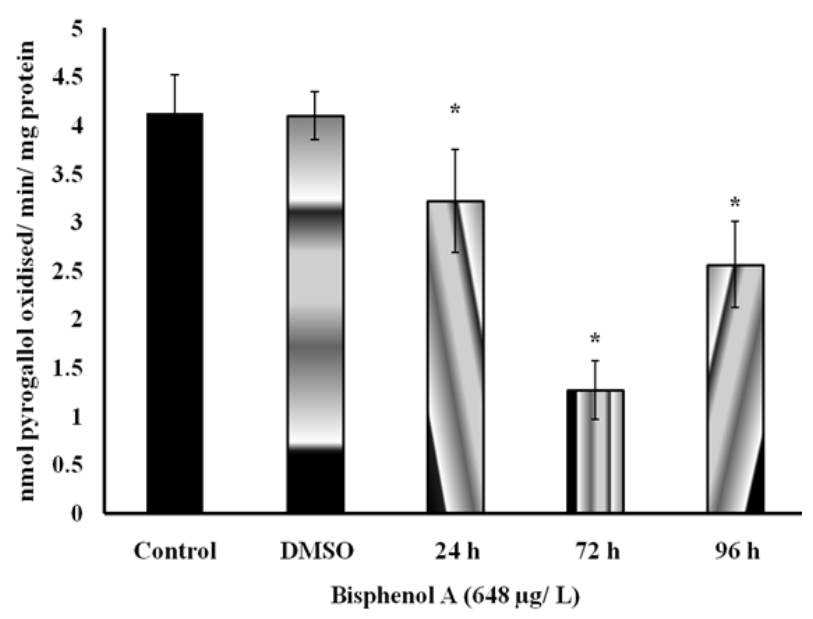

Fig. 3. Effect of bisphenol $A$ on the activity of superoxide dismutase in brain of E. maculates.

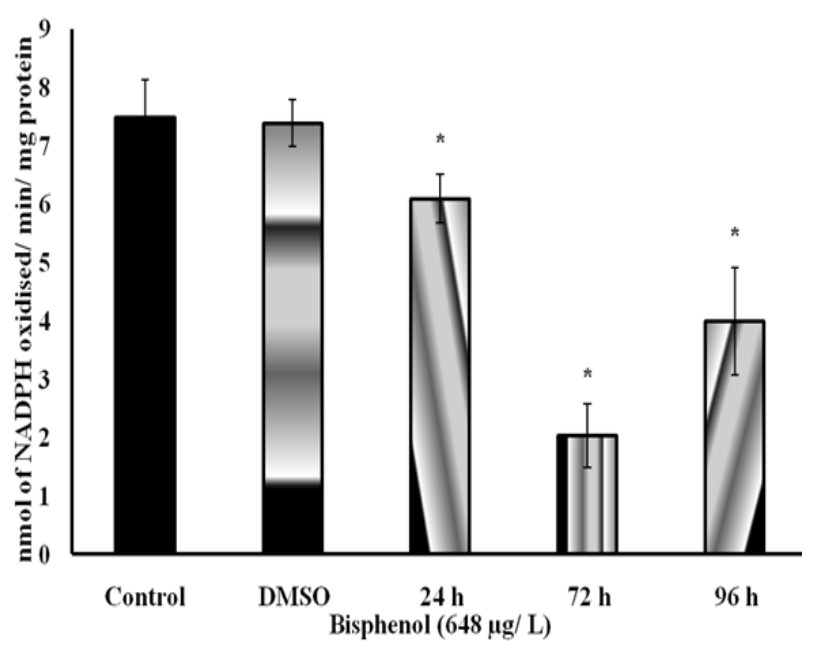

Fig. 5. Effect of bisphenol A on the activity of glutathione reductase in brain of E. maculatus.

dependent decrease at 5\% level of significance in BPA-treated groups when compared with corresponding control groups (Fig 8). Changes in brain

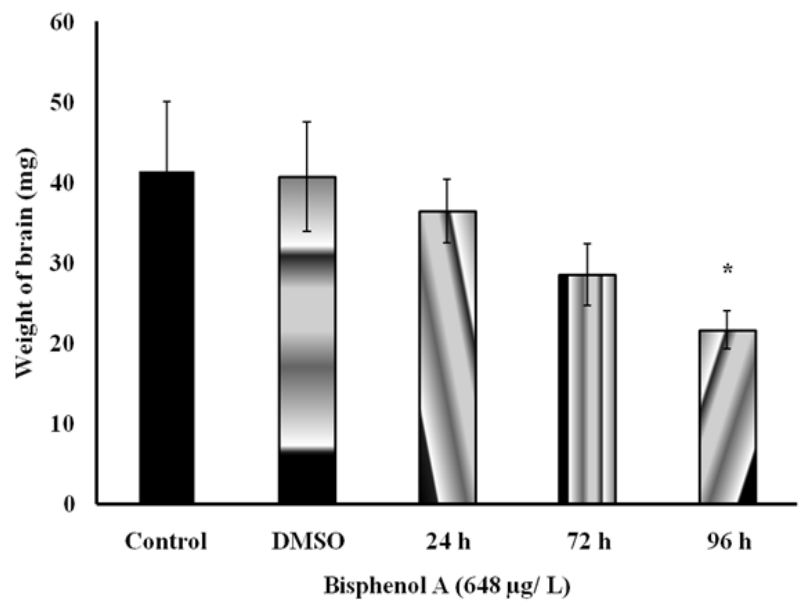

Fig. 2. Effect of bisphenol $A$ on the weights of brain of $E$. maculates.

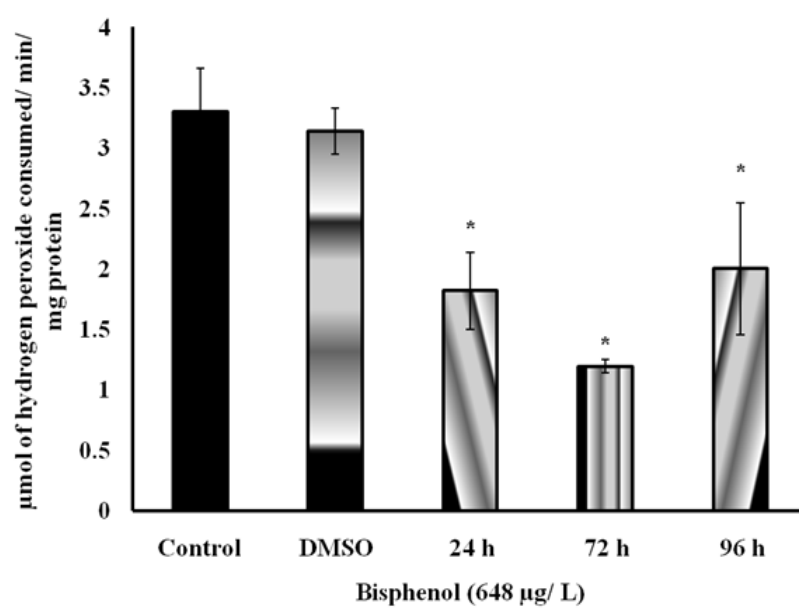

Fig. 4. Effect of bisphenol $A$ on the activity of catalase in brain of E. maculates.

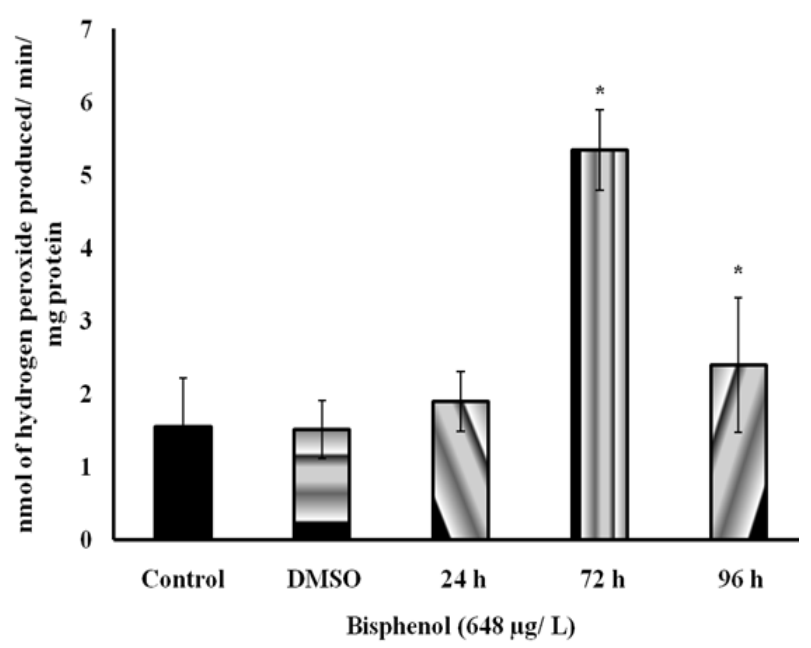

Fig. 6. Effect of bisphenol $A$ on the level of hydrogen peroxide in brain of E. maculatus.

AChE activity probably reflect behavioral changes as movement disturbances, erratic swimming and lethargy because AChE participates in neuronal and neu- 


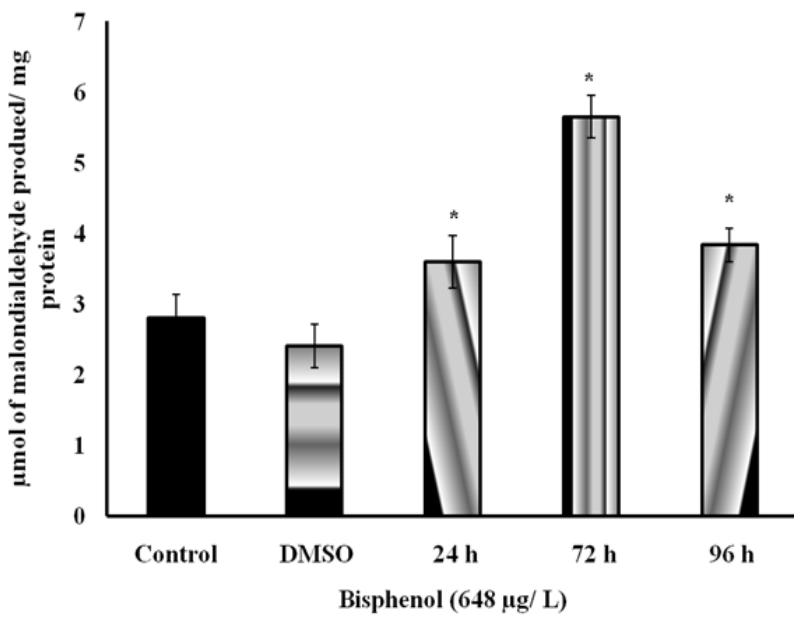

Fig. 7. Effect of bisphenol $A$ on the level of lipid peroxidation in brain of E. maculatus.

romuscular transmissions (Fernandez-Vega et al., 1999). The normal activity of AChE has been shown to be extremely important for many physiological functions, such as prey location, predator evasion and orientation towards food (Miron et al., 2005). In the present study the decrease in body weight due to anorexia or failure to locate food may also be due to decreased $\mathrm{AChE}$ activity in brain. In the present study the brain biomarker enzyme, AChE decreased significantly in brain tissues of all treatment groups in time-dependent manner and therefore it reflects that BPA also affects neuromuscular functions in cichlid fish, E. maculatus.

\section{Conclusion}

From the present study it was evident that the toxicity effect of bisphenol A on brain may be due to induction of reactive oxygen species where it resulted in oxidative stress and the decreased activity of acetyl cholinesterase enzyme reflects that the action of BPA is mediated at neuromuscular junctions. The preliminary investigation thus provide knowledge on increased free radical generation under the condition of exposure to BPA alter the brain antioxidant status of fish, where the induction of oxidative stress in brain could affect the health and behavior of exposed fish.

\section{ACKNOWLEDGEMENTS}

Financial grant from Kerala State Council for Science, Technology and Environment (KSCSTE), Thiruvananthapuram, Kerala is gratefully acknowledged to carry out this study.

\section{REFERENCES}

APHA. (1998). Standard methods for the examination of water and waste water, $20^{\text {th }}$ Edition, Washington, DC.

Asifa, K.P. and Chitra, K.C. (2015a). Evaluation of LC50 and behavioural responses of bisphenol A in the cichlid fish, Etroplus maculatus. Int. J. Curr. Res. 7: 1672516729.

Asifa, K.P. and Chitra, K.C. (2015b). Determination of me-

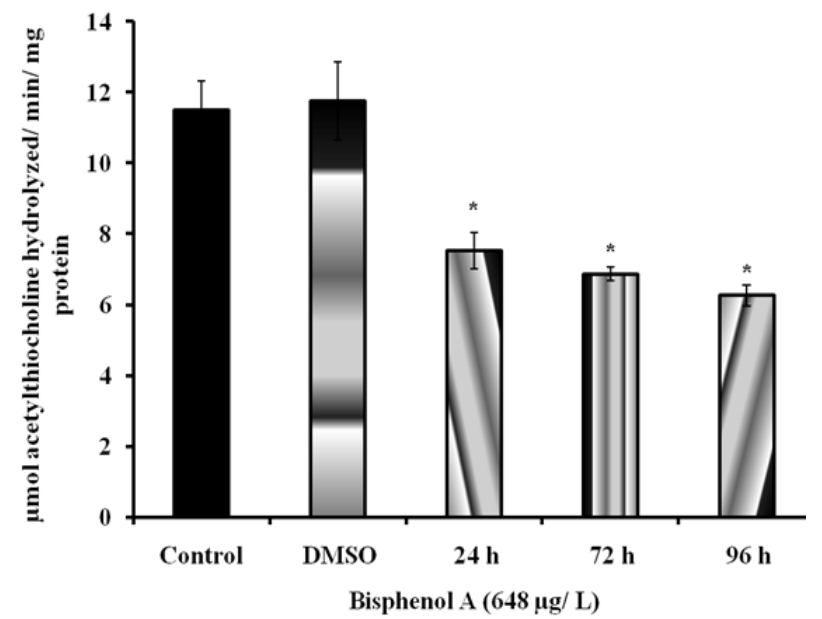

Fig. 8. Effect of bisphenol $A$ on the activity of acetylcholinesterase in brain of $E$. maculatus.

dian lethal concentration $\left(\mathrm{LC}_{50}\right)$ and behavioral changes on the Cichlid fish, Etroplus maculatus exposed to chlordecone. Int. J. Sci. Res. 4: 1473-1475.

Batista, M.T.O., Junior, E.R., Feijó-Oliveira, M., Ribeiro, A.C., Rodrigues, E., Suda, C.N.K. and Vani, G.S. (2014). Tissue levels of the antioxidant enzymes superoxide dismutase and catalase in fish Astyanax bimaculatus from the Una River Basin. Rev. Ambient. Água. 9; 621-631.

Bindhumol, V., Chitra, K.C. and Mathur, P.P. (2003). Bisphenol A induces reactive oxygen species generation in the liver of male rats. Toxicology 188: 117-124.

Carlberg, I. and Mannervik, B.J. (1985). Purification and characterization of the flavoenzyme glutathione reductase from rat liver. J. Biol. Chem. 250: 5474-5480.

Chitra, K.C., Latchoumycandane, C. and Mathur, P.P. (2002). Induction of oxidative stress by bisphenol A in the epididymal sperm of rats. Toxicology 185: 119-127.

Chitra, K.C. and Sajitha, R. (2014). Effect of bisphenol A on the antioxidant defense system and its impact on the activity of succinate dehydrogenase in the gill of freshwater fish, Oreochromis mossambicus. J. Cell Tissue Res. 14: 4219-4226.

Chitra, K.C. and Sr Maiby. (2014). Oxidative stress of bisphenol-A and its adverse effect on the liver of fresh water fish, Oreochromis mossambicus. Int. J. Sci. Res. 3: 221-224.

Claiborne, A. (1985). Catalase activity. In: CRC Handbook of methods for oxygen radical research. $\mathrm{R}$ Greenwald (ed.), CRC Press, Boca Raton, Florida, pp 283-284.

Diamanti-Kandarakis, E., Bourguignon, J.P., Giudice, L.C., Hauser, R., Prins, G.S., Soto, A.M., Zoeller, R.T. and Gore, A.C. (2009). Endocrine disrupting chemicals: an Endocrine Society scientific statement. Endocrine Reviews 30: 293-342.

Ekambaram, P., Narayanan, M. and Jayachandran, T. (2012). Changes in Oxidative Stress and Antioxidant Status in Stressed Fish Brain. Int. J. Sci. Res. 3: 164-170.

Ellman, G.L., Courtney, K.D., Anders, V. and Featherstone, R.M. (1961). A new and rapid colorimetric determination of acetylcholinesterase activity. Biochem. Pharmacol. 3: 88-95.

Fernandez-Vega, C., Sancho, E., Ferrando, M.D. and Andreu, E. (1999). Thiobencarb toxicity and plasma AChE 
inhibition in the European eel. J. Toxicol. Environ. Health B. 34: 6273 .

Halliwell, B. (1993). The role of oxygen radicals in human disease, with particular reference to the vascular system. Pathophysiol. Haemo. T. 23: 118-126.

Howe, S. R. and Borodinsky, L. (1998). Potential exposure to bisphenol A from food-contact use of polycarbonate resins. Food Addit Contam 15: 370-375.

Kabuto, H., Hasuike, S., Minagawa, N. and Shishibori, T. (2003). Effects of bisphenol A on the metabolisms of reactive oxygen species in mouse tissues. Environ. Res. 93: 31-35.

Kang, J.H., Aasi, D. and Katayama, Y. (2007) Bisphenol A in the aquatic environment and its endocrine-disruptive effects on aquatic organisms. Crit. Rev. Toxicol. 37: 607 -625 .

Krishnan, A.V., Stathis, P., Permuth, S.F., Tokes, L. and Feldman, D. (1993). Bisphenol-A: An estrogenic substance is released from polycarbonate flasks during autoclaving. Endocrinology 132: 2279-2286.

Kuiper, G.G., Lemmen, J.G., Carlsson, B., Corton, J.C., Safe, S.H., van der Saag, P.T., van der Burg, B. and Gustafsson, J.A. (1998). Interaction of estrogenic chemicals and phytoestrogens with estrogen receptor beta. Endocrinology 139: 4252-4263.

Kumamoto, T. and Oshio, S. (2013). Effect of fetal exposure to bisphenol $\mathrm{A}$ on brain mediated by $\mathrm{X}$-chromosome inactivation. J. Toxicol. Sci. 38: 485-494.

Livingstone, D.R. (2001). Contaminant-stimulated reactive oxygen species production and oxidative damage in aquatic organisms. Mar. Pollut. Bull. 42: 656-666.

Lowry, O.H., Rosenbrough, N.J., Farr, A.L. and Randall, R.J. (1951). Protein measurement with the Folin phenol reagent. J. Biol. Chem. 193: 265-275.

Marklund, S. and Marklund, G. (1974). Involvement of superoxide anion radical in antioxidation of pyrogallol and a constituent assay for superoxide dismutase. Eur. J. Biochem. 47: 469-474.

Meesters, R.J. and Wa, H.F.S. (2002). Simultaneous determination of 4-nonylphenol and bisphenol $\mathrm{A}$ in sewage sludge. Anal. Chem. 74: 3566-3574.

Miron, D.S., Crestani, M., Shettinger, M.R., Morsch, V.M. Baldisserotto, B., Tierno, M.A., Moraes, G. and Vieira, V.L.P. (2005). Effects of the herbicides clomazone, quinclorac, and metsulfuron methyl on acetylcholinesterase activity in the silver catfish (Rhamdia quelen) (Heptapteridae). Ecotoxicol. Environ. Safety. 61: 98403.
Ohkawa, H., Ohishi, N. and Yagi, K. (1979). Assay for lipid peroxidation in animal tissues by thiobarbituric acid reaction. Anal. Biochem. 95: 351-358.

Pick, E. and Keisari, Y. (1981). Superoxide anion and $\mathrm{H}_{2} \mathrm{O}_{2}$ production by chemically elicited peritoneal macrophages-induced by multiple nonphagocytic stimuli. Cell Immunol. 59: 301-318.

Revathy, V. and Chitra, K.C. (2015). Acute exposure to Diisononyl phthalate (DINP) influenced histopathological and behavioural modification on the freshwater fish, Oreochromis mossambicus (Peters, 1852). Int. J. Res. 2: 464-477.

Safe, S.H., Pallaroni, L., Yoon, K., Gaido, K., Ross, S., Saville, B. and McDonnell, D. (2001). Toxicology of environmental estrogens. Reprod. Fertil. Dev. 13: 307315.

Sahin, E. and Gumuslu, S. (2004). Alterations in brain antioxidant status, protein oxidation and lipid peroxidation in response to different stress models. Behav. Brain. Res. 155: 241-248.

Sikka, S.C. (2001). Relative impact of oxidative stress on male reproductive function. Curr. Med. Chem. 8: 851862.

Sumi, N. and Chitra, K.C. (2015). Consequence of fullerene nanoparticle $\left(\mathrm{C}_{60}\right)$ on oxygen consumption and behavioural modification in Etroplus maculatus. Int. J. Curr. Res. Rev. 7: 40-44

Thiele, .J.J., Freisleben, H.J., Fuchs, J. and Ochsendorf, F.R. (1995). Ascorbic acid and urate in human seminal plasma: determination and interrelationships with chemiluminescence in washed semen. Human Reprod. 10: $110-115$.

U.S. Food and Drug Administration. (2012). Bisphenol A (BPA): Use in Food Contact Application. U.S. Department of Health and Human Services, Food and Drug Administration.

Vandenberg, L.N., Hauser, R., Marcus, M., Olea, N. and Welshons, W.V. (2007). Human exposure to bisphenol A (BPA). Reprod. Toxicol. 24:139-177.

Winston, G.W. and Di Giulio, R.T. (1991). Pro-oxidant and antioxidant mechanisms in aquatic organisms. Aquat. Toxicol. 19: 137-161.

Zhang, Z., Alomirah, H., Cho, H.S., Li, Y.F., Liao, C., Minh, T.B., Mohd M.A., Nakata, H., Ren N. and Kannan K. (2011). Urinary bisphenol A concentrations and their implications for human exposure in several Asian countries. Environ. Sci. Technol. 45: 7044-7050. 